\title{
The Impact of the Construction of Sponge Cities on the Surface Runoff in Watersheds, China
}

\author{
Guoqiang Dong $\mathbb{D}^{1,2,3}$ Baisha Weng $\mathbb{D}^{2,3}$ Tianling Qin, ${ }^{2,3}$ Denghua Yan $\mathbb{D}^{2,3}$ \\ Hao Wang $\mathbb{D}^{2,3}$ Boya Gong $\left.\mathbb{D}\right)^{2,3}$ Wuxia Bi $\mathbb{D}^{2,3}$ and Ziqiang Xing $\mathbb{D}^{2,3}$ \\ ${ }^{1}$ College of Environmental Science and Engineering, Donghua University, Shanghai 201620, China \\ ${ }^{2}$ State Key Laboratory of Simulation and Regulation of Water Cycle in River Basin, China Institute of Water Resources and \\ Hydropower Research, Beijing 100038, China \\ ${ }^{3}$ China Institute of Water Resources and Hydropower Research, Beijing 100038, China
}

Correspondence should be addressed to Denghua Yan; yandh@iwhr.com

Received 2 December 2017; Accepted 12 February 2018; Published 20 March 2018

Academic Editor: Stefano Dietrich

Copyright (C) 2018 Guoqiang Dong et al. This is an open access article distributed under the Creative Commons Attribution License, which permits unrestricted use, distribution, and reproduction in any medium, provided the original work is properly cited.

In order to study the effect of the construction of the sponge cites on the process of urban water circulation in China, we analyzed the precipitation data from 756 stations across China between 1961 and 2011 and national land-use data in 2014. The spatial distribution characteristics of built-up area and amount of annual average runoff interception in sponge cities were explored in five different zonal scale levels. Assuming that the sponge cities have been built at the national-level construction land and the volume capture ratio of annual runoff is taken as $85 \%$, the amount of annual average runoff interception in sponge cities is $988.58 \times 10^{8} \mathrm{~m}^{3}$ during 1961 to 2011 in China, where the annual precipitation is greater than or equal to $400 \mathrm{~mm}$. The cities with more amount of annual average runoff interception are mostly distributed in Beijing-Tianjin-Hebei region, the Yangtze River Delta, and the Pearl River Delta. As to the Haihe River Basin, the annual average amount of surface water resources is $135.69 \times 10^{8} \mathrm{~m}^{3}$ between 2005 and 2014 , and the amount of annual average runoff interception is $219.58 \times 10^{8} \mathrm{~m}^{3}$ from 1961 to 2011 . The construction of sponge cities has the greatest impact on the surface water resources in the Haihe River Basin. Taking $80 \%-85 \%$ as the volume capture ratio of annual runoff in sponge cities is not reasonable, which may lead to the irrational exploitation and utilization of regional water and soil resources.

\section{Introduction}

Rapid urbanization has become a critical issue in the 21st century $[1,2]$. In developing countries, like China, urbanization has been considered as an index of development. Urbanization is one kind of the important land use and thus land cover changes on runoff and floods within watersheds are the main research topics in past few decades [3].

In China, the urbanization rate (the percentage of urban population) has increased from $12.5 \%$ to $50 \%$ from 1952 to 2011 [4]. The rapid expansion of built-up area has become the major feature of land-use changes in China, which has led to a built-up area vacancy and inefficient land uses $[5,6]$. Statistical data showed that the urban population of China increased from 172.45 million to 777.82 million from 1978 to 2012, coupling with an increase of the urbanization level from $17.92 \%$ to $52.57 \%$. What is more, the number of cities increased from 193 to 660 during this period [7].

Due to the growth of urban areas, rural land cover types (e.g., soil, water, and vegetation) have been replaced by urban materials including asphalt, concrete, and metal $[8,9]$. These replacements have profound environmental impacts, such as forest degradation, agricultural lands loss, air, soil and water contamination, increased water use and runoff, and reduced biodiversity [10-13].

The loss of pervious surfaces and the replacement of natural pathways with artificial drainage reduce the infiltration into soils. This combination is generally considered to have a significant effect on the hydrological response of an area to rainfall, such as faster response [14], greater magnitude of river flow [15], higher recurrence of small floods $[16,17]$, and lower base flow and reduced groundwater 
recharge [18]. The reality is often further complicated by the installation of storm water retention systems, and the import/export of water to/from a catchment. For example, some studies suggest that leakage from water mains can sustain base flow during dry periods, whereas storm water drains coupled with retention features can attenuate flows [19].

In the context of urbanization, more than 10 million people in rural areas are migrating into urban areas in China every year, and the quantity of newly constructed buildings takes half part of the world's total buildings. Under such circumstances, it is of great importance that the urban surface runoff will be greatly increased, which will cause floods, ecological deterioration of river system, and increased water pollution. Sponge city functions can retain rainwater, and then the recycling water can patch up the contaminated rainwater runoff [20].

Rainfall in most cities usually flows into the nearest rivers and lakes through the local drainage system. However, many of the drainage systems across the country are almost underdeveloped, thus leading to significant floods during heavy rainfalls. But under the new "sponge city" program, nearly 70 percent of excess rain water will be recycled and reused on greenery, street cleaning, and fire-fighting.

A "sponge city" refers to a city where its urban underground water system operates like a sponge to absorb, store, leak, and purify rainwater and release it for reuse when necessary. Following the philosophy of "solving a city's problems with its own resources," it aims at storing rainwater, especially during heavy rainfall seasons, to prevent floods and releasing it for the benefit of residents during dry times. This will also mitigate a city's water shortage.

The control target of total runoff was proposed in Sponge City Development Technical Guide: Low Impact Development [21]. The target should be consistent with the law of natural hydrological cycle, must comply with the rational principle of technical and economic, and can be strongly implemented. The determination of control objectives is affected by the regional climate characteristics, water resources, urban development intensity, utilization of rainwater resources and waterlogging drainage requirements, soil geological conditions, economic conditions, and so on. How to reasonably determine the total amount of the runoff control target is the first issue to be solved in the implementation of the total runoff control [22]. The volume capture ratio of annual runoff is the primary goal of the construction of sponge cities. The higher the value, the better the comprehensive benefits of environmental protection and waterlogging prevention, which means the greater the project investment and difficulty of implementation. In this way, the volume capture ratio of annual runoff has a great impact on the urban planning and design of the sponge city [23]. At present, 30 cities were selected as the pilot cities of the sponge cities construction in China. They can be divided into five regions in the mainland of China and give the minimum and maximum limit values of the volume capture ratio of annual runoff $(\alpha)$, that is, region I $(85 \% \leq \alpha \leq 90 \%)$, region II $(80 \% \leq \alpha \leq 85 \%)$, region III $(75 \% \leq \alpha \leq 85 \%)$, region IV $(70 \% \leq \alpha \leq 85 \%)$, and region $\mathrm{V}$ $(60 \% \leq \alpha \leq 85 \%)$. It should define these limit values all over
China, then determining the control targets of total runoff under local conditions [21].

In this study, we applied ArcGIS as the technical support platform. The objectives of this study are intended to solve the following issues: (1) the spatial distribution of the builtup area of China in 2014; (2) the spatial distribution of annual runoff coefficient; (3) the spatial distribution of annual average precipitation in China from 1961 to 2011; (4) the annual average runoff interception of the built-up area in China from 1961 to 2011, where the annual precipitation is greater than or equal to $400 \mathrm{~mm}$; and (5) the impacts of sponge cities construction on surface runoff in the watersheds.

\section{Data and Methods}

2.1. Data. There are 336 evaluation units as research objects in this study, including 332 regional administrative units designated by the Ministry of Civil Affairs of the People's Republic of China and four municipalities, that is, Beijing, Shanghai, Tianjin, and Chongqing. This study did not cover Chaohu municipality (which was revoked in 2011), Hong Kong, Macao, or Taiwan regions.

China is divided into ten hydrological regions, which are depicted in Figure 1(a). These hydrological regions are located in different latitudinal zones ranging from arid and semiarid regions to semihumid and subtropical ones.

The data used in this study were (a) land-use data (2014) from the Data Center for Resources and Environmental Sciences, Chinese Academy of Sciences; (b) daily precipitation data of the 756 meteorological stations in a 51-year period (from 1961 to 2011) from the China Meteorological Data Sharing Service System (Figure 1(b)); and (c) annual runoff coefficient, which is obtained from digitizing to Hydrological Atlas of China by ArcGIS.

2.2. Methodology. The calculation result is presented in form of annual precipitation amount of 756 meteorological stations from 1961 to 2011. The spatial distributions in the scale of China and different hydrological regions are drawn from averages of annual data for each station.

Based on the interpolation of observation data, the spatially continuous distribution of raster data was obtained to achieve data grid. Through the comparison and analysis of several interpolation methods (e.g., Inverse Distance Weighted, Kriging, Natural Neighbor, and Spline), the interpolation result of the inverse distance weighted (IDW) interpolation method is optimal in the study area; thus, the spatial distribution maps of annual average precipitation for a 51-year period in China were gained by using the IDW method. The proportion of total rainfall that becomes runoff within a certain catchment area represents runoff coefficient. The data of surface runoff was calculated based on the data of annual runoff coefficient and precipitation.

The contour lines of annual runoff coefficient were obtained from digitizing to Hydrological Atlas of China by ArcGIS. Then, we used the Topo to Raster tool in ArcGIS to get the annual runoff coefficient, using contour lines and quoted points as input file, known as standard Topo to Raster. 


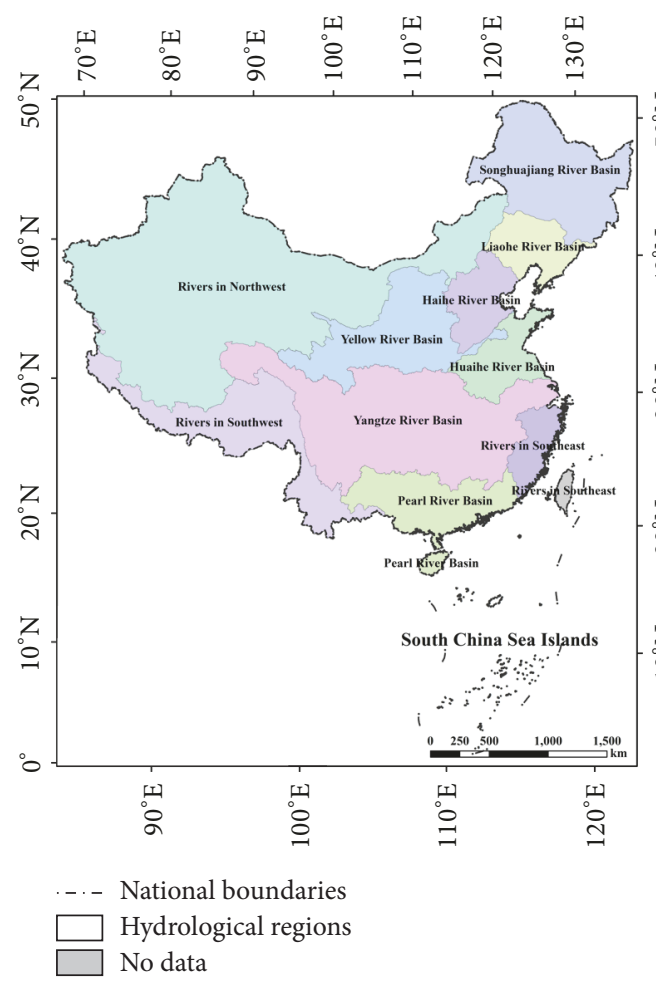

(a)

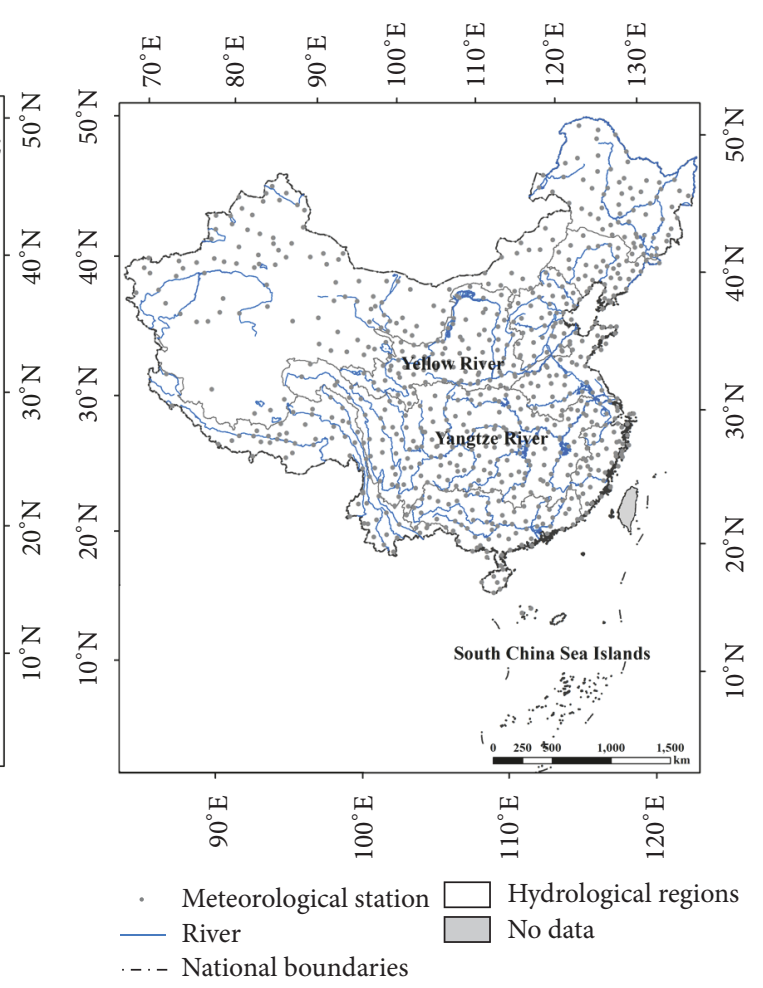

(b)

FIgURE 1: Ten hydrological regions (a) and geographical distribution of the 756 stations (b) in China.

In this study, we proposed to normalize the results obtained from the Zonal Statistics in ArcGIS. We have used the sum values of different zones (in the same scale) to obtain runoff interception per unit area. We used the zonal statistics tool in ArcGIS to get the sum index of each zone for five different zonal levels (i.e., first-order zones of water resource, second-order zones of water resource, third-order zones of water resource, province zones, and city zones).

The volume capture ratio of annual runoff is a percentage, which is the cumulative annual control (not discharged) of the total annual rainfall in the field, by means of natural and artificial enhancement, such as infiltration, storage, and evaporation [24]. According to the experiences of developed countries, the optimal volume capture ratio of annual runoff is $80 \%-85 \%$, and in this study, the ratio is taken as $85 \%$ [21].

Assuming that the sponge cities have been built in the construction land, then there will be a significant change of runoff in the built-up area between before and after the completion construction of the sponge city. This study assumes that the volume capture ratio of annual runoff is $85 \%$; that is, $85 \%$ of the runoff will be trapped in the sponge city area. Under this assumption, the interception of runoff was calculated in the sponge cities. At last, zonal statistics were adopted in study region, where the annual precipitation is greater than or equal to $400 \mathrm{~mm}$.

In a certain region, the amount of precipitation in builtup area $\left(P_{\text {urban }}\right)$ is calculated as

$$
P_{\text {urban }}=\mathrm{PCT}_{\text {urban }} \times P_{\text {ave }},
$$

where $\mathrm{PCT}_{\text {urban }}$ is the area proportion of built-up area in the region (\%); $P_{\text {ave }}$ is the annual average precipitation over the region $(\mathrm{mm})$.

The runoff interception in a sponge city $\left(\mathrm{RI}, \mathrm{m}^{3}\right)$ equation is as follows:

$$
\mathrm{RI}=P_{\text {urban }} \times A_{\text {urban }} \times \alpha,
$$

where $A_{\text {urban }}$ is the area of the sponge city $\left(\mathrm{km}^{2}\right) ; \alpha$ is the volume capture ratio of annual runoff in the sponge city.

\section{Results and Discussion}

3.1. Spatial Distribution of Annual Precipitation in China. Based on the daily precipitation data obtained from 756 meteorological stations (from 1961 to 2011) and $90 \mathrm{~m} \times 90 \mathrm{~m}$ Digital Elevation Model (DEM) of China [25], spatial distribution of precipitation in China has been studied in this paper.

Studies have demonstrated that precipitation is quite unevenly distributed across China, with higher values in the southeastern coastal areas and decreasing in the northwestern inlands. This fact is illustrated in Figure 2(a), which shows the spatial distribution of annual precipitation in China from 1961 to 2011. In Figure 2(a), annual average precipitation during this period is $588 \mathrm{~mm}$. The least annual precipitation is only $8 \mathrm{~mm}$ and the largest is $2,724 \mathrm{~mm}$.

The distribution of annual regional precipitation is uneven in China. Table 1 shows an obvious difference of precipitation of river basins between the South and the North. 


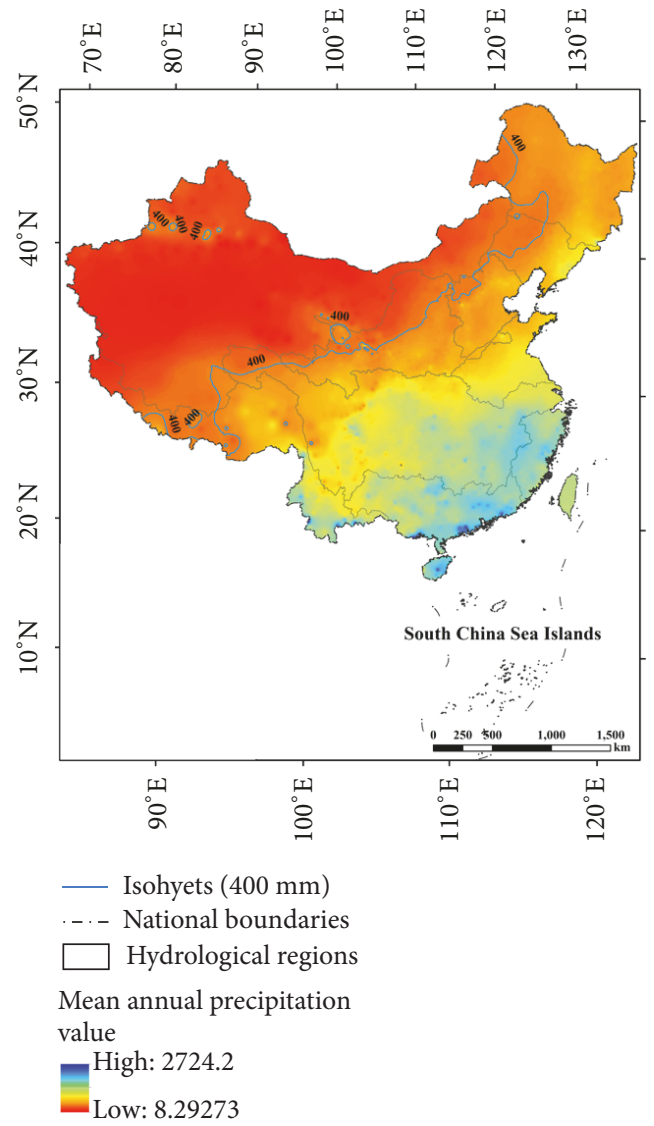

(a)

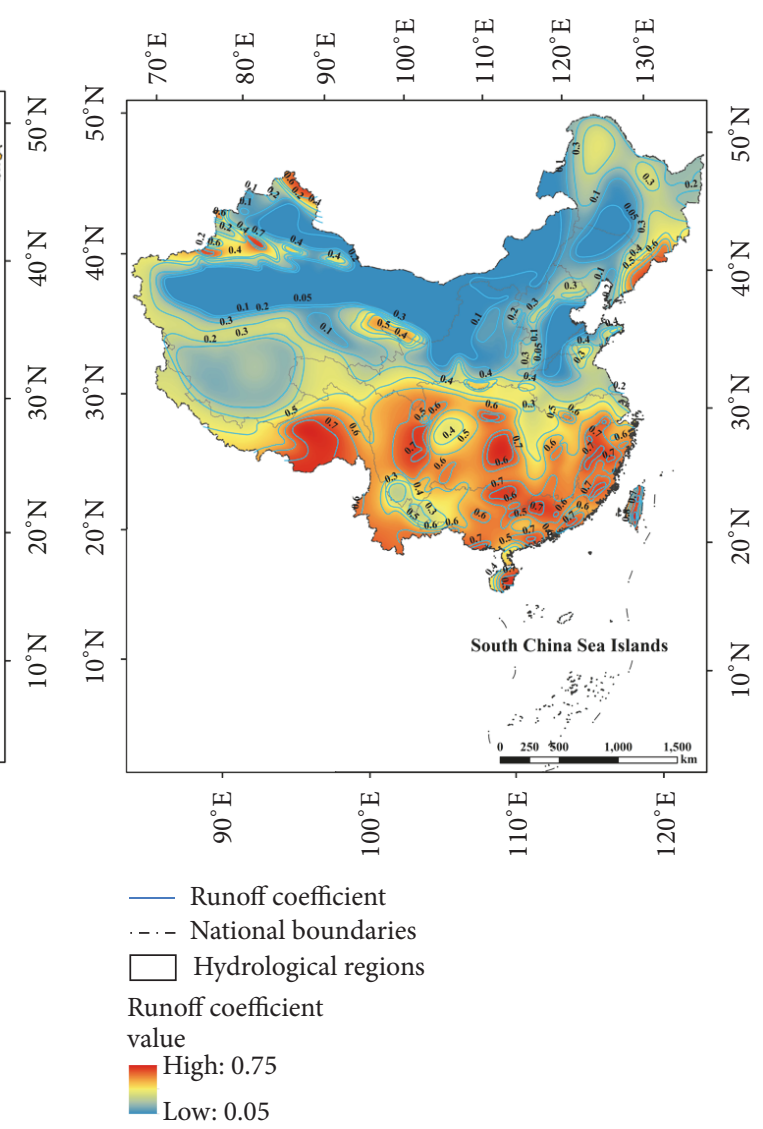

(b)

FIGURE 2: Spatial distribution of mean annual precipitation for a 51-year period (a) and annual runoff coefficient (b) in China.

TABLE 1: Annual average precipitation (1961-2011), runoff interception (1961-2011), and surface water resources amount (2005-2014) of firstorder zones of water resource in China.

\begin{tabular}{|c|c|c|c|c|c|}
\hline & $\begin{array}{l}\text { First-order zones of } \\
\text { water resource }\end{array}$ & Precipitation (mm) & $\begin{array}{l}\text { Surface water } \\
\text { resources amount } \\
\left(10^{8} \mathrm{~m}^{3}\right)\end{array}$ & $\begin{array}{c}\text { Runoff } \\
\text { interception } \\
\left(10^{8} \mathrm{~m}^{3}\right)\end{array}$ & Proportion $^{1}$ \\
\hline \multirow{5}{*}{$\begin{array}{l}\text { North river } \\
\text { basins }\end{array}$} & $\begin{array}{c}\text { Songhuajiang River } \\
\text { Basin }\end{array}$ & 490.69 & $1,279.37$ & 4.22 & $0.33 \%$ \\
\hline & Rivers in Northwest & 150.30 & $1,282.69$ & 0.02 & $0.00 \%$ \\
\hline & Liaohe River Basin & 541.23 & 393.95 & 9.71 & $2.46 \%$ \\
\hline & Haihe River Basin & 520.75 & 135.69 & 219.58 & $161.82 \%$ \\
\hline & Yellow River Basin & 444.04 & 562.88 & 13.61 & $2.42 \%$ \\
\hline \multirow{5}{*}{$\begin{array}{l}\text { South river } \\
\text { basins }\end{array}$} & Pearl River Basin & $1,537.62$ & $4,679.89$ & 426.39 & $9.11 \%$ \\
\hline & Huaihe River Basin & 845.30 & 699.48 & 52.48 & $7.50 \%$ \\
\hline & Yangtze River Basin & $1,036.30$ & $9,263.06$ & 237.54 & $2.56 \%$ \\
\hline & Rivers in Southwest & 657.18 & $5,477.61$ & 1.05 & $0.02 \%$ \\
\hline & Rivers in Southeast & $1,568.74$ & $2,082.66$ & 23.99 & $1.15 \%$ \\
\hline & & 6254.53 & $25,857.28$ & 988.58 & $3.82 \%$ \\
\hline
\end{tabular}

Note. ${ }^{1}$ Proportion $=($ runoff interception $) /($ surface water resources amount $) ;$ [annual average precipitation data of surface water resources amount are reproduced by permission of the China water resources bulletin (2005-2014)]. 
The average rainfall in the southern river basins is observed at more than $600 \mathrm{~mm}$, while those of the Pearl River Basin and Rivers in Southeast are $1,537 \mathrm{~mm}$ and $1,568 \mathrm{~mm}$, respectively. Annual rainfall in the northern river basins is observed at $600 \mathrm{~mm}$ or less, with the least in the Rivers in Northwest of only $150 \mathrm{~mm}$. It is to be noted that the difference of precipitation in the river basins is one of the main reasons for the uneven distribution of water resources in China.

In China, this uneven distribution of precipitation can result in many acute environmental problems, such as water shortages, floods and soil erosion, and ecosystem degradation.

\subsection{Spatial Distribution of Built-Up Area in 2014 and Annual} Runoff Coefficient in China. Land-use types of built-up area extraction are based on the national land use (2014). The total area of urban built-up area differed greatly in space. Overall, the total area for eastern region is the largest, followed by the central and the west regions.

The construction land area is $67,400 \mathrm{~km}^{2}$ in 2014 by statistics. The land areas for construction in Beijing-Tianjin-Hebei region, the Yangtze River Delta, and the Pearl River Delta are $8,200 \mathrm{~km}^{2}, 11,200 \mathrm{~km}^{2}$, and $5,600 \mathrm{~km}^{2}$, respectively, and the ratio of national corresponding area for construction in these above three regions is $12.17 \%, 17.92 \%$, and $8.29 \%$, respectively. The total area of construction land of Beijing-Tianjin-Hebei region, the Yangtze River Delta, and the Pearl River Delta is $25,900 \mathrm{~km}^{2}$, which accounts for $38.38 \%$ of the country and is close to $2 / 5$ of the national total construction area.

The spatial distribution of built-up area in 2014 in China can be seen in Figure 3. The built-up areas are mainly concentrated on Beijing-Tianjin-Hebei region, the Yangtze River Delta, and the Pearl River Delta because these regions have witnessed dramatic industrialization and urbanization.

Runoff coefficient is a dimensionless factor which is used to convert the rainfall amounts to runoff, represents the integrated effect of catchment losses, and hence depends upon the nature of land surface, slope, degree of saturation, and rainfall intensity. Runoff coefficient is also affected by the proximity to water table, degree of soil compaction, porosity of soil, vegetation, and depression storage [26]. An ArcGIS tool has been used to create a runoff coefficient map for potential areas in China in this paper. As is shown in Figure 2(b), storm water runoff quantity in urban area increases along with the expansion of impermeable land surface in construction.

3.3. Spatial Distribution of Runoff Interception in Sponge Cites. The capture ratio of annual runoff represents the hydrologic effects of annual rainfall infiltration, storage, utilization, evaporation, and transpiration. There is an inherent relationship among the annual runoff volume capture, volumetric runoff coefficient, and flow runoff coefficient [27].

As shown in Table 1, the amount of annual average runoff interception in sponge cities is $988.58 \times 10^{8} \mathrm{~m}^{3}$ from 1961 to 2011 in China where the annual precipitation is no less than $400 \mathrm{~mm}$, and they are mainly distributed in Pearl River Basin, Haihe River Basin, and Yangtze River Basin (Figure 4(a)). The amount of rainfall-runoff interception in Pearl River Basin,

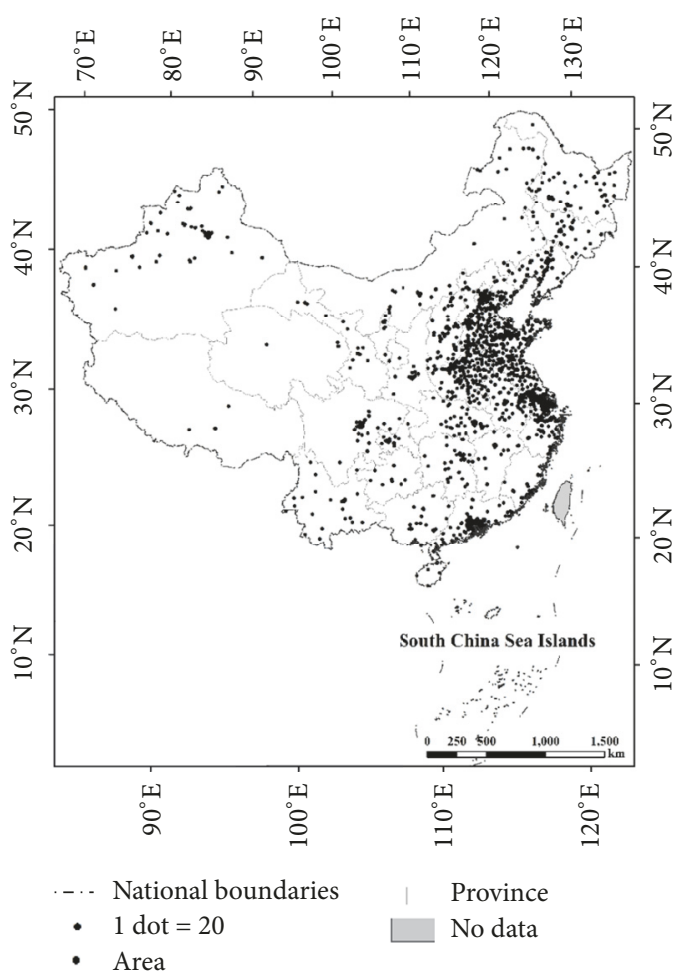

FIGURE 3: Spatial distribution of built-up area in 2014 in China. One dot represents $20 \mathrm{~km}^{2}$ (unit: $\mathrm{km}^{2}$ ).

Haihe Basin, and Pearl River Basin is $426.39 \times 10^{8} \mathrm{~m}^{3}, 219.58$ $\times 10^{8} \mathrm{~m}^{3}$, and $237.54 \times 10^{8} \mathrm{~m}^{3}$; accounting for $43.13 \%, 22.21 \%$, and $24.03 \%$ of total amount of rainfall-runoff interception, respectively. The sum of the rainfall-runoff interception in the three river basins above is $883.51 \times 10^{8} \mathrm{~m}^{3}$, accounting for $89.37 \%$ of total amount of rainfall-runoff interception.

For the second-order zones of water resource (Figure 4(b)), the amount of annual average runoff interception in sponge cities is $731.88 \times 10^{8} \mathrm{~m}^{3}$, accounting for $74.03 \%$ of the total amount, which is mainly distributed in the Northern Haihe River Basin, Taihu River Basin, Dongjiang River Basin, and Pearl River Delta. The amount of annual average runoff interception in the Northern Haihe River Basin, Taihu River Basin, Dongjiang River Basin, and Pearl River Delta is 193.52 $\times 10^{8} \mathrm{~m}^{3}, 137.85 \times 10^{8} \mathrm{~m}^{3}, 170.04 \times 10^{8} \mathrm{~m}^{3}$, and $230.47 \times$ $10^{8} \mathrm{~m}^{3}$, accounting for $19.58 \%, 13.94 \%, 17.20 \%$, and $23.31 \%$ of total amount, respectively.

For the third-order zones of water resource (Figure 4(c)), the amount of annual average runoff interception in sponge cities is $484.11 \times 10^{8} \mathrm{~m}^{3}$, accounting for $48.97 \%$ of total amount, which is mainly distributed in plain of the lower reaches of Beisi River, Dongjiang River Delta, and downwards of Qiuxiangjiang in Dongjiang River, with values of $152.75 \times$ $10^{8} \mathrm{~m}^{3}, 169.23 \times 10^{8} \mathrm{~m}^{3}$, and $162.13 \times 10^{8} \mathrm{~m}^{3}$, accounting for $15.45 \%, 17.12 \%$, and $16.40 \%$, respectively.

At the provincial level (Figure 4(d)), the amount of annual average runoff interception in sponge cities varies significantly. The amount of annual average runoff interception in Guangdong province is $412.45 \times 10^{8} \mathrm{~m}^{3}$, accounting for 


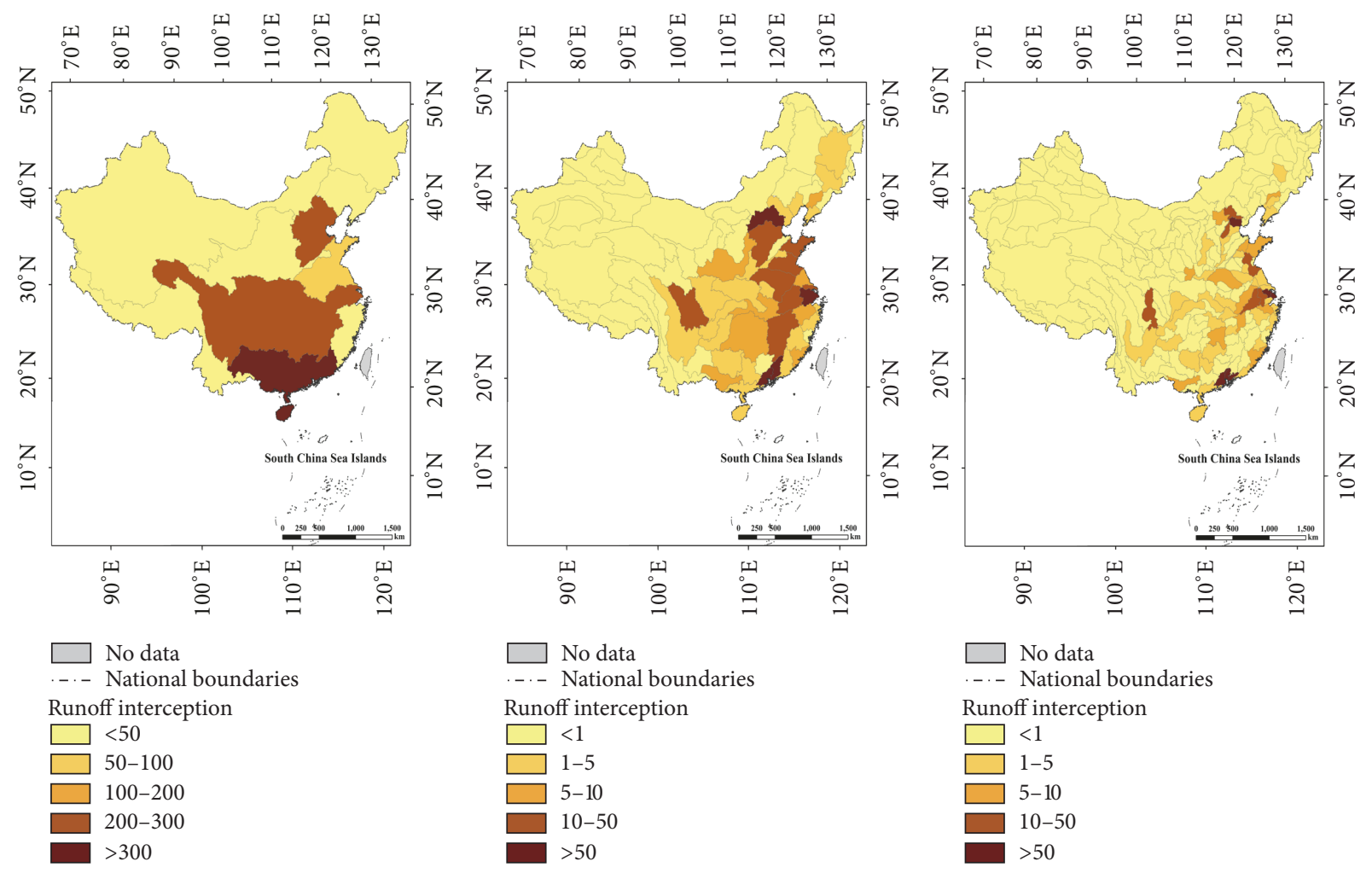

(a)

(b)

(c)

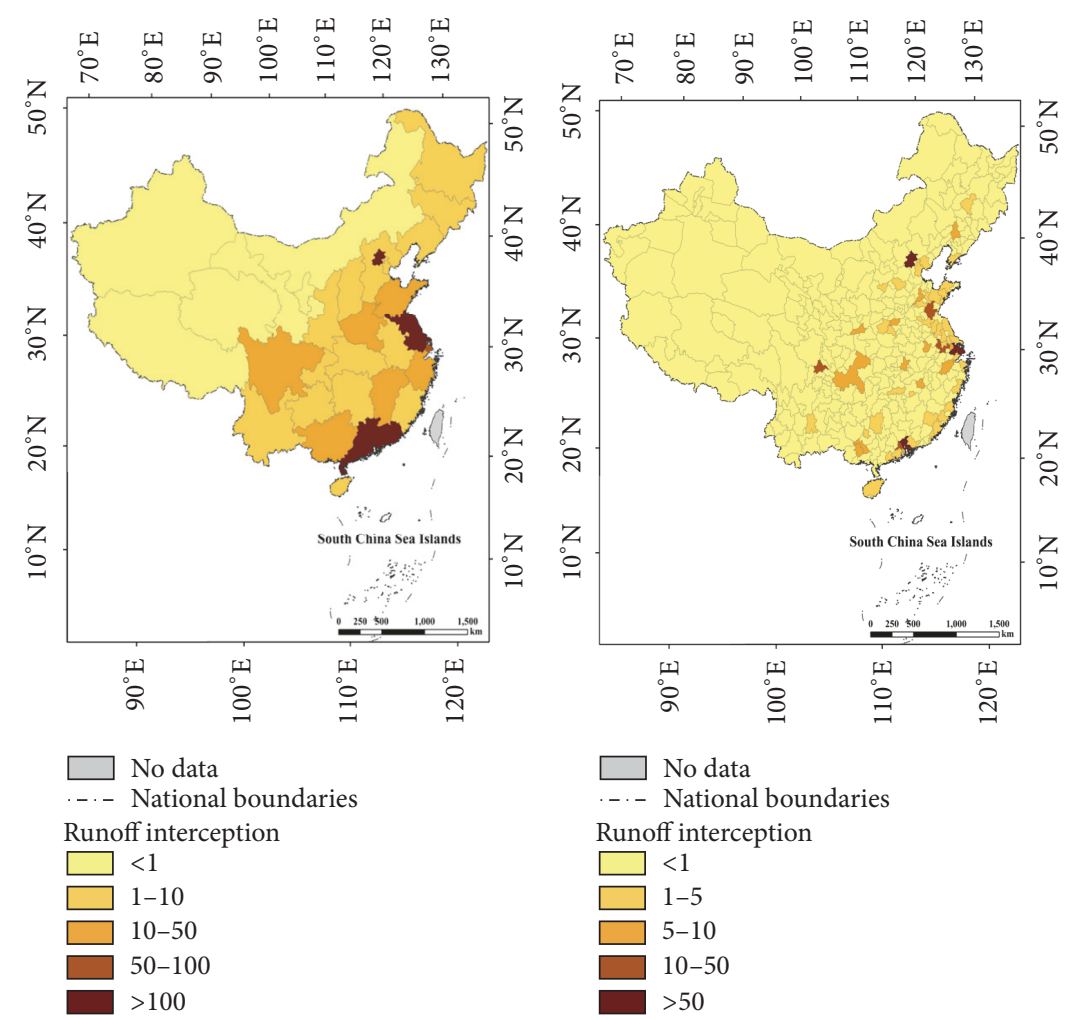

(d)

(e)

FIGURE 4: Annual runoff interception of five different zonal scale levels in China (unit: $10^{8} \mathrm{~m}^{3}$ ): (a) first-order zones of water resource, (b) second-order zones of water resource, (c) third-order zones of water resource, (d) province zones, and (e) city zones. 
$41.72 \%$ of total amount, ranking first, followed by Beijing, which is $203.28 \times 10^{8} \mathrm{~m}^{3}$, accounting for $20.56 \%$ of total amount. Jiangsu takes the third place, with an amount of annual average runoff interception of $111.55 \times 10^{8} \mathrm{~m}^{3}$, accounting for $11.28 \%$ of total amount.

At the city level (Figure 4(e)), three municipal administrative regions with the maximum amount of annual average runoff interception in sponge cities are Beijing city, Shenzhen city (Guangdong province), and Dongguan city (Guangdong province). The amount of annual average runoff interception is $203.28 \times 10^{8} \mathrm{~m}^{3}, 176.22 \times 10^{8} \mathrm{~m}^{3}$, and $141.90 \times 10^{8} \mathrm{~m}^{3}$, accounting for $20.56 \%, 17.83 \%$, and $14.35 \%$ of total amount, respectively. The total annually average runoff interception amount is $521.83 \times 10^{8} \mathrm{~m}^{3}$, which accounts for $52.79 \%$ of the national value. They are closely followed by Guangzhou city (Guangdong province), Shanghai city, and Suzhou city (Jiangsu province), with the average runoff interception of $55.22 \times 10^{8} \mathrm{~m}^{3}, 52.79 \times 10^{8} \mathrm{~m}^{3}$, and $52.26 \times 10^{8} \mathrm{~m}^{3}$, respectively.

The annual average surface water resources amount is $25,857.28 \times 10^{8} \mathrm{~m}^{3}$ in China and $135.69 \times 10^{8} \mathrm{~m}^{3}$ in the Haihe River Basin. Meanwhile, the amount of annual average runoff interception in the Haihe River Basin is $219.58 \times 10^{8} \mathrm{~m}^{3}$, which is more than 1.6 times of the annual average surface water resources amount. The Pearl River Basin has the biggest annual average runoff interception but still accounts for no more than $10 \%$ of the surface water resources amount. Thus, the construction of sponge cities has the greatest impact on the surface water resources in the Haihe River Basin. Therefore, it needs to consider the characteristics of runoff in the basin in determination of the volume capture ratio of annual runoff.

3.4. Discussion. The amount of annual average runoff interception in sponge cities is $988.58 \times 10^{8} \mathrm{~m}^{3}$ from 1961 to 2011 in China, with the annual precipitation being greater than or equal to $400 \mathrm{~mm}$, and they are mostly distributed in BeijingTianjin-Hebei region, the Yangtze River Delta, and the Pearl River Delta. There are two reasons. Firstly, Beijing-TianjinHebei region, the Yangtze River Delta, and the Pearl River Delta are regarded as Three Economic Circles of China and Three Major Urban Agglomerations in China. In these areas, urbanization is rapid, cities are bigger, and the built-up area is larger and more concentrated. Secondly, the annual mean amount of precipitation is large in the Yangtze River Delta and the Pearl River Delta. The proportion of urban impervious area is increased, and the surface runoff is easy to form. If the sponge cities are built in these areas, the volume capture ratio of annual runoff will be $80 \%-85 \%$; then most of the runoff will be trapped in cities.

In recent years, the water in the Haihe River Basin has decreased, and the production capacity of the surface water has reduced, and the runoff has diminished obviously. It is climate change and human activities that caused these consequences. According to hydrological series evaluation from 1956 to 2000, in the Haihe River Basin, the annual average precipitation was $535 \mathrm{~mm}$, and the annual average runoff was $216 \times 10^{8} \mathrm{~m}^{3}$. And during 1999 to 2008 , the annual average precipitation and annual average runoff were $476 \mathrm{~mm}, 107 \times$ $10^{8} \mathrm{~m}^{3}$ respectively. Compared with the average of those from 1956 to 2000 , the annual average precipitation has reduced by $11 \%$, and the annual average runoff has reduced by $50 \%$ during the period of 1999 to 2008 [28]. If the sponge cities are built in the Haihe River Basin and the volume capture ratio of annual runoff is $85 \%$, the runoff interception in sponge cities will be greater than the surface runoff of the watershed.

According to spatial distribution of built-up area, annual average precipitation, and annual average runoff coefficient, combined with China's water resources distribution in different partitions, it is unreasonable to take the capture rate of annual runoff in sponge city as $80 \%-85 \%$. It may lead to the unreasonable exploitation and utilization of regional water and soil resources. And it will not be good for the sustainability of economy and social development in the basin region and will do harm to the regional ecological environment system.

The process of urbanization is a dynamic process in China, and the development of each city is not the same. With a large number of assumptions to do data generalization processing, it may be inconsistent with the actual situation, and the results would be biased. Therefore, the method should be further improved, to apply specific and detailed analysis to different cities.

\section{Conclusions}

Based on the precipitation data from 756 stations across China during 1961 to 2011 and national land-use data in 2014, this research mainly focuses on the spatial distribution characteristics of precipitation and built-up area, and the amount of annual average runoff interception in sponge cities.

The major conclusions are as follows:

(1) Assuming that the sponge cities have been built at the national-level construction land and the volume capture ratio of annual runoff is $85 \%$, the amount of annual average runoff interception in sponge cities is $988.58 \times 10^{8} \mathrm{~m}^{3}$ during 1961 to 2011 in China, where the annual precipitation is greater than or equal to $400 \mathrm{~mm}$, and they are mostly distributed in Pearl River Basin, Haihe River Basin, and Yangtze River Basin.

(2) As to the Haihe River Basin, the amount of annual average surface water is $135.69 \times 10^{8} \mathrm{~m}^{3}$ from 2005 to 2014 , and the amount of annual average runoff interception is $219.58 \times 10^{8} \mathrm{~m}^{3}$ from 1961 to 2011 , which is more than 1.6 times greater than the amount of annual average surface water. Taking $80 \%-85 \%$ as the volume capture ratio of annual runoff in sponge cities is not reasonable, which may lead to the irrational exploitation and utilization of regional water and soil resources. And it will not be positive for the sustainability of economy and social development in the basin and do harm to the regional ecological environment system. If the sponge cities have been built in the Haihe River Basin, most of the runoff will be trapped in cities, and only a small portion of runoff is discharged. Thereby it will reduce the ecological water demand of some ecological environment (rivers, lakes, swamps, greenbelt, forests, etc.) in the lower reaches of the sponge cities. Moreover, these may even lead to the drying 
up of northern rivers and lakes, shrinkage of wetlands, forest death, and then deterioration of ecological environment.

In accordance with the concept of low impact development and to maintain regional positive hydrological cycle and economy rationality, we must control the runoff discharge standard which is nearly unchanged before and after development and construct the natural landscapes. However, as China is vast and has a variety of natural landscapes, in most parts of western China, the natural landscapes are mostly deserted before the city grows, and the runoff is very small. If the buildings are based on this as a benchmark, it will cause excessive rainwater collection and redundant emission reduction, which leads to the atrophy of the original water or the virtuous circle of water system. In terms of economic benefit, when the capture rate of annual runoff exceeds a certain value, the benefit of investment will drop sharply, which results in significant large scale of facilities and investment waste [22].

\section{Conflicts of Interest}

The authors declare that they have no conflicts of interest.

\section{Acknowledgments}

This study was funded by the National Key Research and Development Project (no. 2016YFA0601503); the Chinese National Natural Science Foundation (no. 91547209); and the Representative Achievements and Cultivation Project of State Key Laboratory of Simulation and Regulation of Water Cycle in River Basin (no. 2016CG02).

\section{References}

[1] J. D. Miller, H. Kim, T. R. Kjeldsen, J. Packman, S. Grebby, and R. Dearden, "Assessing the impact of urbanization on storm runoff in a peri-urban catchment using historical change in impervious cover," Journal of Hydrology, vol. 515, pp. 59-70, 2014.

[2] B. Zhang, G.-D. Xie, N. Li, and S. Wang, "Effect of urban green space changes on the role of rainwater runoff reduction in Beijing, China," Landscape and Urban Planning, vol. 140, pp. 816, 2015.

[3] J. Du, L. Qian, H. Rui et al., "Assessing the effects of urbanization on annual runoff and flood events using an integrated hydrological modeling system for Qinhuai River basin, China," Journal of Hydrology, vol. 464-465, pp. 127-139, 2012.

[4] H. Jia, H. Yao, Y. Tang, S. L. Yu, R. Field, and A. N. Tafuri, "LIDBMPs planning for urban runoff control and the case study in China," Journal of Environmental Management, vol. 149, pp. 6576, 2015.

[5] B. Yu, S. Shu, H. Liu et al., "Object-based spatial cluster analysis of urban landscape pattern using nighttime light satellite images: a case study of China," International Journal of Geographical Information Science, vol. 28, no. 11, pp. 2328-2355, 2014.

[6] S. Zhang, "Land-centered urban politics in transitional China Can they be explained by Growth Machine Theory?" Cities, vol. 41, pp. 179-186, 2014.

[7] Y. Chen, Z. Chen, G. Xu, and Z. Tian, "Built-up land efficiency in urban China: Insights from the General Land Use Plan (2006-2020)," Habitat International, vol. 51, pp. 31-38, 2016.
[8] Y.-C. Weng, "Spatiotemporal changes of landscape pattern in response to urbanization," Landscape and Urban Planning, vol. 81, no. 4, pp. 341-353, 2007.

[9] H. Xu, "A new index for delineating built-up land features in satellite imagery," International Journal of Remote Sensing, vol. 29, no. 14, pp. 4269-4276, 2008.

[10] European Environment Agency (EEA), Urban Sprawl in Europe-The Ignored Challenge, Office for Official Publications of the European Communities, Luxembourg, 2006.

[11] C. Goksel, N. Musaoglu, M. Gurel, N. Ulugtekin, A. Tanik, and D. Z. Seker, "Determination of land-use change in an urbanized district of Istanbul via remote sensing analysis," Fresenius Environmental Bulletin, vol. 15, no. 8 A, pp. 798-805, 2006.

[12] L. M. Santana, "Landsat ETM+ image applications to extract information for environmental planning in a Colombian city," International Journal of Remote Sensing, vol. 28, no. 19, pp. 42254242, 2007.

[13] A. Schneider, M. A. Friedl, and D. Potere, "Mapping global urban areas using MODIS 500-m data: New methods and datasets based on "urban ecoregions", Remote Sensing of Environment, vol. 114, no. 8, pp. 1733-1746, 2010.

[14] H.-J. Huang, S.-J. Cheng, J.-C. Wen, and J.-H. Lee, "Effect of growing watershed imperviousness on hydrograph parameters and peak discharge," Hydrological Processes, vol. 22, no. 13, pp. 2075-2085, 2008.

[15] R. J. Hawley and B. P. Bledsoe, "How do flow peaks and durations change in suburbanizing semi-arid watersheds? A southern California case study," Journal of Hydrology, vol. 405, no. 1-2, pp. 69-82, 2011.

[16] G. E. Hollis, "The effect of urbanization on floods of different recurrence interval," Water Resources Research, vol. 11, no. 3, pp. 431-435, 1975.

[17] I. Braud, P. Breil, F. Thollet et al., "Evidence of the impact of urbanization on the hydrological regime of a medium-sized periurban catchment in France," Journal of Hydrology, vol. 485, pp. 5-23, 2013.

[18] D. L. Simmons and R. J. Reynolds, "EFFECTS OF URBANIZATION ON BASE FLOW OF SELECTED SOUTH-SHORE STREAMS, LONG ISLAND, NEW YORK," JAWRA Journal of the American Water Resources Association, vol. 18, no. 5, pp. 797805, 1982.

[19] M. Scholz and S. Kazemi Yazdi, "Treatment of road runoff by a combined storm water treatment, detention and infiltration system," Water, Air, \& Soil Pollution, vol. 198, no. 1-4, pp. 55-64, 2009.

[20] B. Qiu, "The connotation, approach and prospect of thesponge city (LID)," Construction Science and Technology, vol. 1, pp. 1118, 2015 (Chinese).

[21] "Ministry of Housing and Urban-Rural Construction of the People's Republic of China (MOHURD)Sponge City Development Technical Guide: Low Impact Development," http://www .mohurd.gov.cn/zcfg/jsbwj_0/jsbwjcsjs//_219465.html.10.

[22] J. Li, W. Wang, W. Che, C. Liu, and Y. Zhao, "Explanationof sponge city development technical guide: regional division for total rainfall runoff volume capture target," China Water and Wastewater, vol. 31, no. 8, pp. 6-12, 2015 (Chinese).

[23] D. Kang and Q. Ye, "Study on evaluation and decomposition of volume capture ratio of annual rainfall in sponge city," China Water and Wastewater, vol. 31, no. 19, pp. 126-129, 2015 (Chinese). 
[24] G. Pan, W. Che, J. Li, and H. Li, "Urban runoff pollution control quantity and its design rainfall in China," China Water and Wastewater, vol. 24, no. 22, pp. 25-29, 2008 (Chinese).

[25] Z. Liu, X. Zhang, and R. Fang, "Analysis of spatial interpolation methods to precipitation in Yulin based on DEM," Journal of Northwest A \& F University (Natural Science Edition), vol. 38, no. 7, pp. 227-234, 2010 (Chinese).

[26] M. K. Goel, "Runoff Coefficient," in Encyclopedia of Snow, Ice and Glaciers, Encyclopedia of Earth Sciences Series, pp. 952953, Springer Netherlands, Dordrecht, 2011.

[27] X. Ren and W. Tang, "Application of capture ratio oftotal annual runoff volume in spongy city," China Water and Wastewater, vol. 31, no. 13, pp. 105-109, 2015.

[28] C. Di and X. Yang, "Modeling and dynamical analysis of the water resources supply-demand system: A case study in haihe river basin," Journal of Applied Mathematics, vol. 2014, no. 11-12, Article ID 171793, pp. 1-10, 2014. 

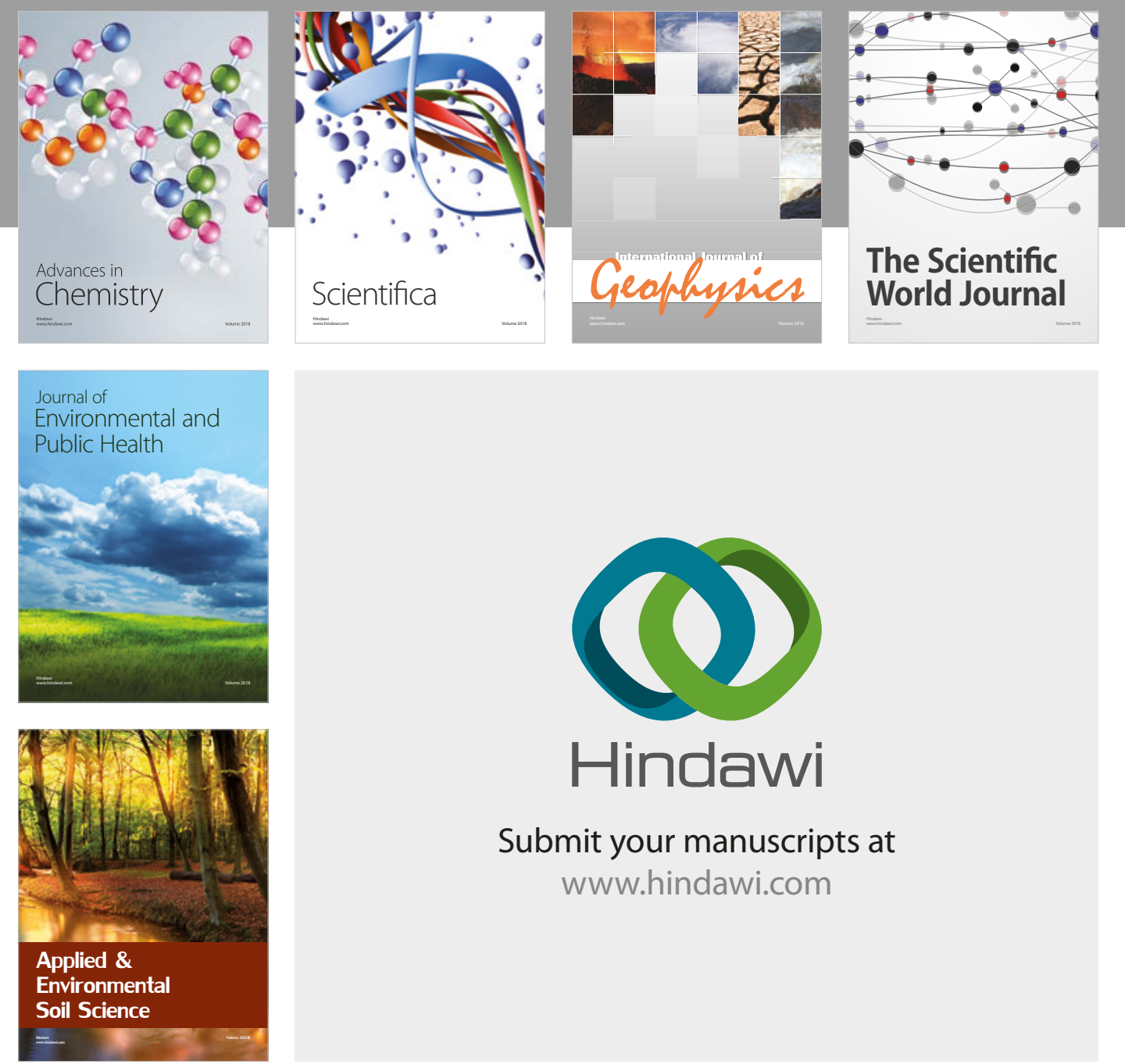

The Scientific

\section{World Journal}
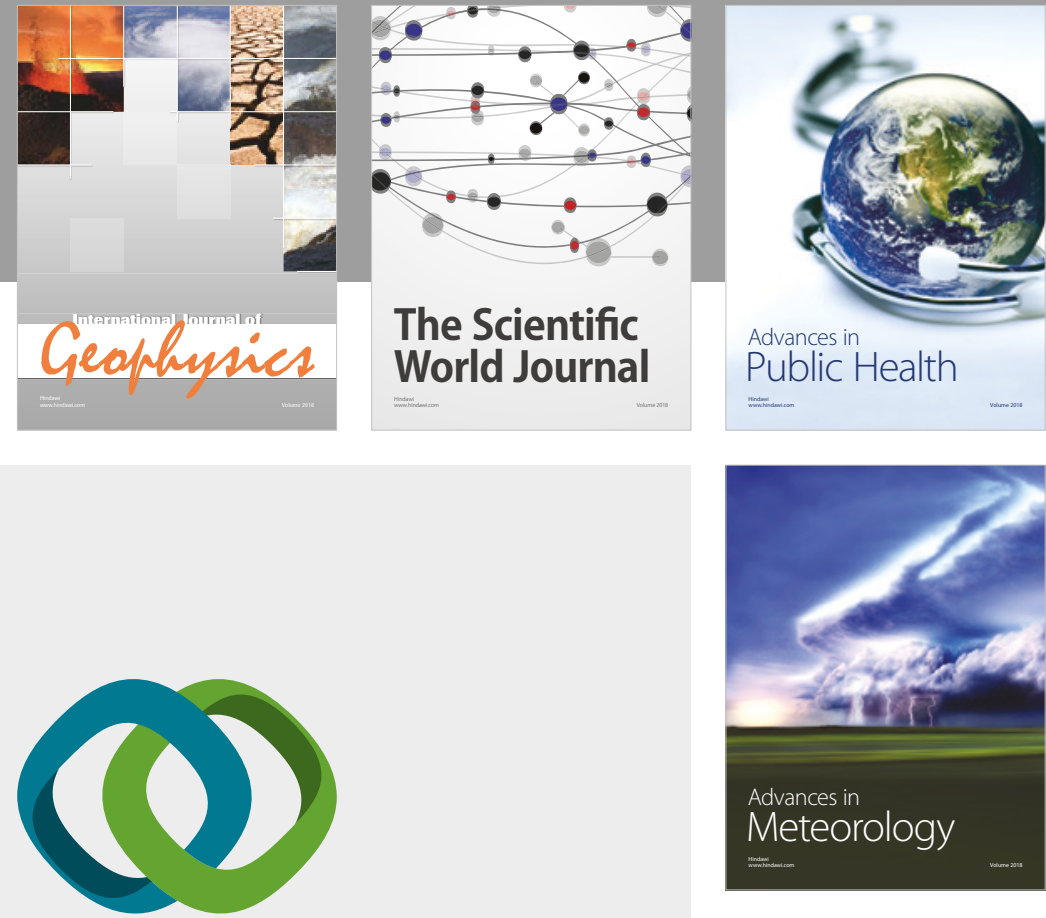

Advan

Public Health

\section{Hindawi}

Submit your manuscripts at

www.hindawi.com
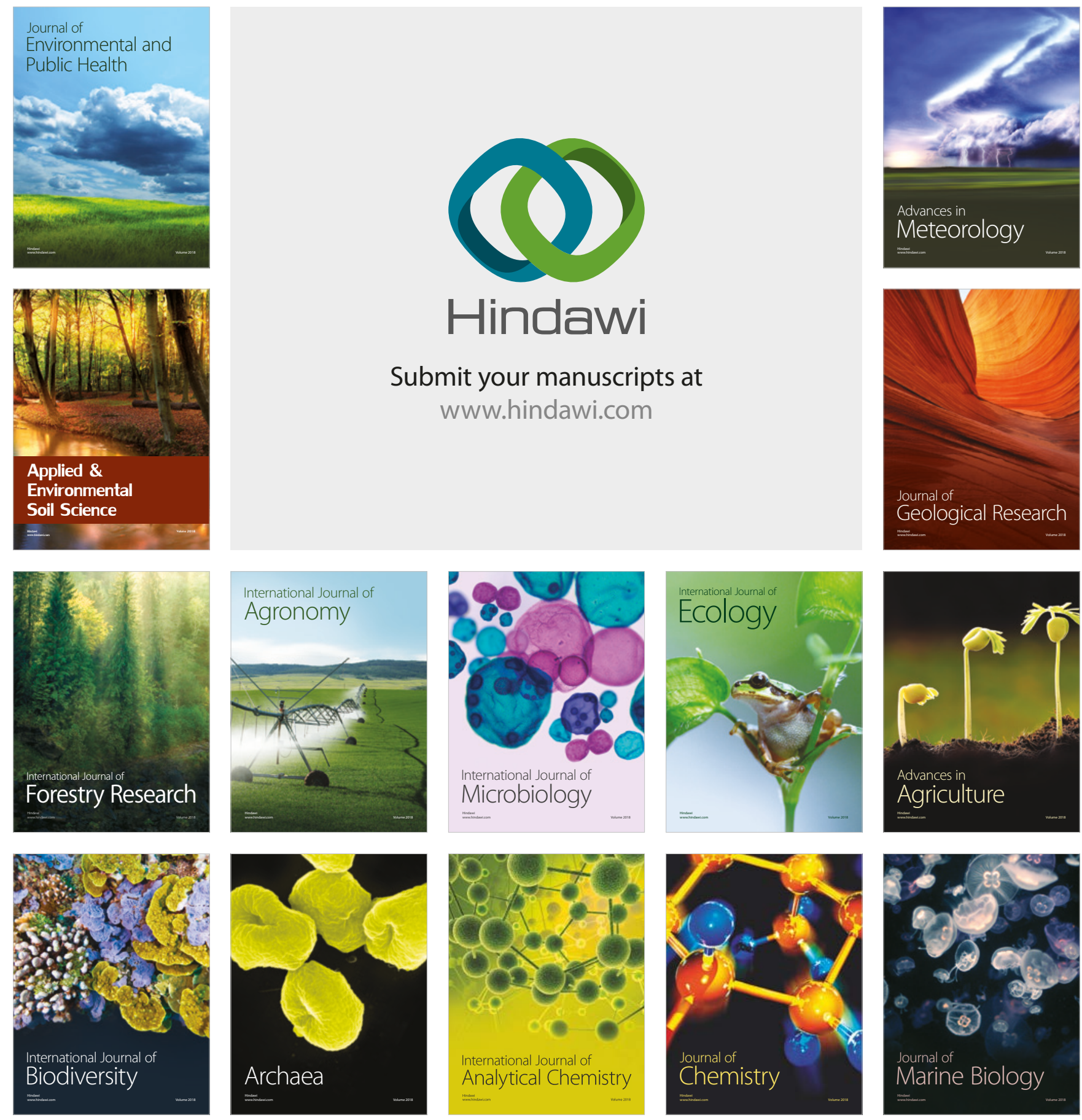